\title{
An experimental approach to microbial carbonate precipitation in improving the engineering properties of sandy soils
}

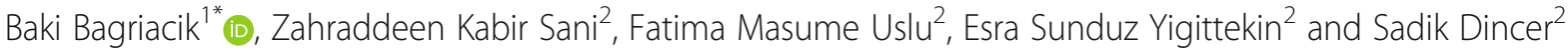

\begin{abstract}
Purpose: Stabilization of weak soil can be achieved through different methods, some of which include jet column, cement stabilization and fly ash stabilization. Unfortunately, the use of the aforementioned methods of soil improvement affects the environment negatively thereby leading to environmental degradation. With the aforesaid impediment in mind, the need for devising methods of weak soil improvement becomes pertinent.
\end{abstract}

Methods: Bacillus sp. - a non-pathogenic organism found abundantly in soil — was investigated in this study as a potential agent of soil improvement. The usability of Bacillus sp. in soil improvement was investigated with direct shear tests and permeability tests under optimum conditions in this study.

Result: Time-dependent study on the effect of the ureolytic bacteria Bacillus sp.-induced calcium carbonate precipitation shows reduction in permeability and increase in the strength of the soil under study. On exhaustion of the available nutrients in the soil, however, the strength of the soil is not negatively impacted.

Conclusion: Microbially induced calcium precipitation by Bacillus sp. is effective in soil improvement as such it may serve as substitute for conventional soil stabilization techniques. The ability of the bacteria to precipitate calcium carbonate in the soil leads to reduction in the permeability and increase in the shear strength of the soil.

Keywords: Soil improvement, Bacillus sp., Time-dependent behaviour, Sustainability, Microbial carbonate precipitation, Sandy soil

\section{Background}

Numerous studies have been conducted to assess the effect of microbially precipitated calcium carbonate on the permeability and strength of poor soils. Changes in compressibility, permeability and strength of the treated soil depend on numerous environmental conditions which interfere with microbial response towards specific reagents by so doing affecting their ability to precipitate calcite. Water accumulation in the soil can be a problem for civil engineering structures. When the load from the superstructure is transferred to the soil, there may be different settlements and swelling problems on the ground due to

\footnotetext{
* Correspondence: bakibagriacik@gmail.com

'Department of Civil Engineering, Faculty of Engineering, Cukurova

University, Balcali, 01330 Adana, Turkey

Full list of author information is available at the end of the article
}

the water in the soil. In addition, in such environments, depending on the soil type, there may be a risk of liquefaction during an earthquake. Thus, the accumulation of water on the soil damages the civil engineering structure. So low water permeability in the soil will prevent such problems. For the past few years, utilizing the ability of bacteria to precipitate calcium carbonate $\left(\mathrm{CaCO}_{3}\right)$ has been found to be a promising eco-friendly approach of soil improvement (DeJong et al., 2006). The evolvement of an alkaline microenvironment as a result of bacterial physiological activity leads to the deposition of calcium carbonate (Douglas and Beveridge, 1998).

Ureolytic bacteria had been employed in conducting significant investigations on carbonate precipitation by bacteria (Stocks et al., 1999). Ureolytic bacteria enhance the precipitation of $\mathrm{CaCO}_{3}$ through the production of

(c) The Author(s). 2021 Open Access This article is licensed under a Creative Commons Attribution 4.0 International License, which permits use, sharing, adaptation, distribution and reproduction in any medium or format, as long as you give appropriate credit to the original author(s) and the source, provide a link to the Creative Commons licence, and indicate if changes were made. The images or other third party material in this article are included in the article's Creative Commons licence, unless indicated otherwise in a credit line to the material. If material is not included in the article's Creative Commons licence and your intended use is not permitted by statutory regulation or exceeds the permitted use, you will need to obtain permission directly from the copyright holder. To view a copy of this licence, visit http://creativecommons.org/licenses/by/4.0/. 
the enzyme urease. Urease enzyme catalyses the hydrolysis of urea to $\mathrm{CO}_{2}$ and ammonia thereby causing an increase in $\mathrm{pH}$ concentration and carbonate (Stocks et al., 1999). Bacterial precipitation of calcium carbonate has been found to elevate the bearing capacity of soil (Lo Bianco and Madonia, 2007; Dejong et al., 2006). Bacterial calcium carbonate precipitation has been utilized in the crack repair of granite and concrete (Gollapudi et al., 1995, Ramachandran et al. 2001; Bang et al. 2001; Ramakrishnan, 2007; Jonkers et al., 2009). These precipitations were found to fill pores, reduce permeability through the enhancement of particle bonding (Ivanov and Chu, 2008; Whiffin et al., 2007).

Previous researches have pointed the bacteria Bacillus pasteurii - which exhibits high urease production capability - as a potential candidate suitable for been utilized in biocementation (Bang et al., 2001; Dejong et al., 2010; Bachmeier et al., 2002, Sarda et al., 2009). The researches indicate that biocementation can serve as an effective technique in reducing soil permeability. Because of the damage that moisture causes to building foundations, the need arises for altering the permeability of the foundation soil. Despite the fact that numerous researches have been conducted with the aim of reducing soil permeability, there is limited research on the utilization of bacteria in this field. Ferris et al. (1997) and Whiffin et al. (2007) have observed that biocementation in sandy soil reduced permeability significantly. Nemati and Voordouw (2003) found that calcite cementation in sandstone reduced permeability by $98 \%$. Biocementation arises due to microbial activities that lead to the production of particulate binding materials (calcite) thereby improving the soil structure (Ferris et al., 1997; Nemati and Voordouw, 2003; Whiffin et al., 2007). In addition to enhancing the shear strength of tropical soil, bacterial calcite precipitates have been reported to reduce the permeability of tropical soil. However, high salinity has an inhibitory effect on calcite precipitation by the bacteria (Soon et al. 2013-2014). Whiffin et al. (2007) reported $22-75 \%$ soil permeability reduction. On treating soil with the enzyme urease, Yasuhara et al. (2012) reported a permeability reduction of $60-70 \%$. So also, inoculating soil with the bacteria Bacillus megaterium has been reported to induce a $90 \%$ reduction in hydraulic conductivity (Soon et al., 2014; Umar et al., 2016).

Calcite precipitation reduces the pore cavities of soil and by extension effecting permeability reduction (DeJong et al., 2010). Chu et al. (2012) studied shear strength and hydraulic conductivity of soil using the ureolytic bacteria Sporosarcina pasteurii isolated from tropical coastline soil. In the study, it was stated that cracks occur on the soil surface due to some conditions such as climatic conditions; these cracks were amended with the produced calcium carbonate layers. Accordingly, the effect of calcium carbonate on the cracking modulus of the ground became stronger and was stated to be $35.9 \mathrm{MPa}$. Microbially induced calcium precipitation is stated to be a ground breaking technique in soil improvement (Filet et al. 2012).

Bio-mineralized calcium carbonate was found to be effective in increasing the bearing capacity of soil and reducing its permeability and settling. Ivanov and Chu (2008) by utilizing bio-mineralized calcium carbonate to improve the engineering properties of soil have shown that it can be used in geotechnical engineering. Yasuhara et al. (2012) utilized urease enzyme obtained from sources other than microbial in catalysing urea hydrolysis within the proximity of calcium chloride and found out that dramatical increase in strength and 60\% reduction in hydraulic conductivity of the treated soil occurred. Canakci et al. (2015) investigated the effect of bacterially induced calcium carbonate precipitate on the compressibility and strength of organic soil and found that bacterial treatment enhances the compressibility and shear strength of the organic soil. Although several researches utilizing Bacillus $s p$. in sandy soil improvement have been conducted, significant studies investigating the effect of time-dependent Bacillus sp. treatment on the strength and permeability of poorly graded soils have not been conducted. In the study conducted by Harianto et al. (2013), unconfined compression and permeability tests were carried out for different curing times on soils prepared using Bacillus sp. At the end of 28 days, an increase of $60 \%$ in the bearing capacity of the soil was observed. In addition, an $80 \%$ improvement in permeability values was observed at the end of 28 days. Therefore, 28 days were determined as the optimum curing time in terms of bearing capacity and permeability. In a study conducted by Hasriana et al. (2018), bearing capacity values were calculated for different Bacillus sp. ratios during a 7-day cure period. According to the results, it was found that as the amount of Bacillus increased, the bearing capacity increased up to 13 times. In another study conducted by Osinubi et al. (2019), bearing capacity values were calculated for samples prepared with different water content using Bacillus sp. The bearing capacity of soils with different water content was determined to be at most $278.0 \mathrm{kN} / \mathrm{m}^{2}$ without Bacillus sp. This bearing capacity increased up to a maximum of $1835.5 \mathrm{kN} / \mathrm{m}^{2}$ with the use of Bacillus $s p$. As a result, an increase in bearing strength of up to 6.6 times was observed. Studies on the use of Bacillus show that hydraulic permeability decreases by around $60 \%$ in a short time, and decreases up to $90 \%$ depending on time. In addition, it has been understood from the literature that there is an increase in the bearing capacity of soils from 6.6 to 13 times. It was seen that Bacillus is an alternative method in reducing the hydraulic permeability and increasing the bearing capacity of soils. 


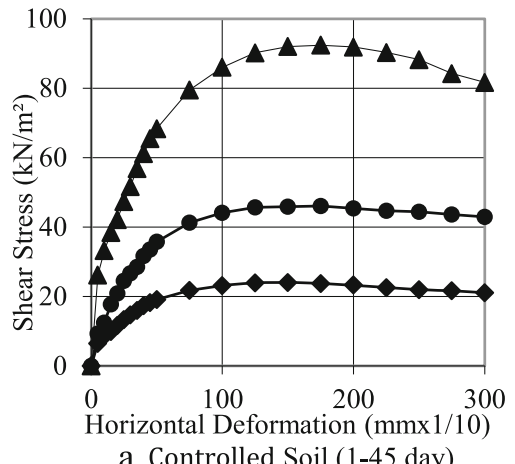

a. Controlled Soil (1-45 day)

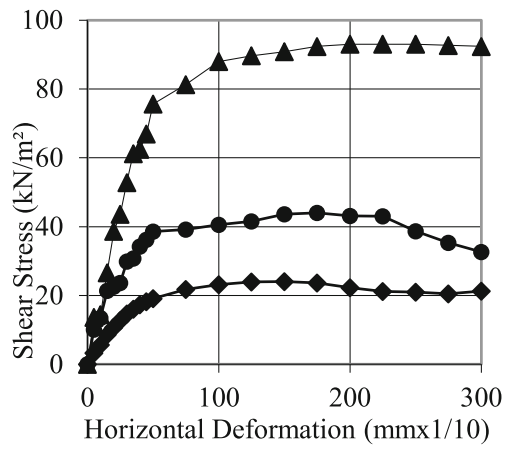

c. Treated Soil on day 2

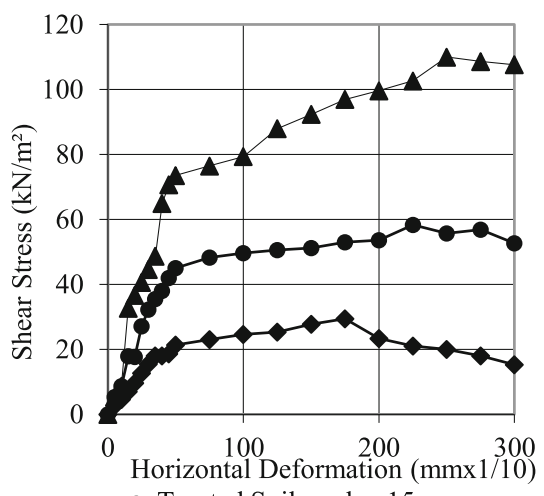

e. Treated Soil on day 15

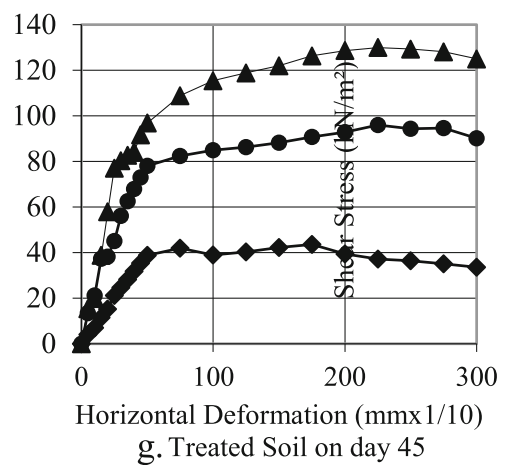

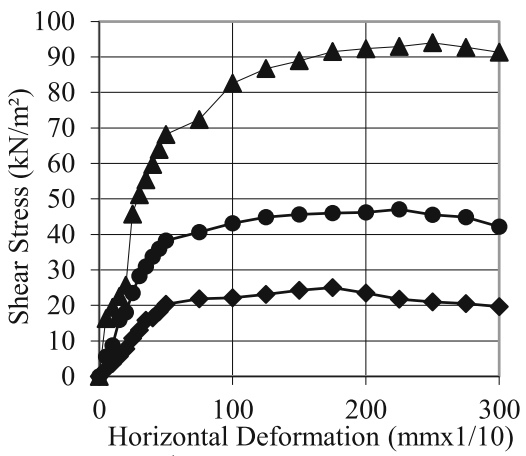

b. Treated Soil on day 1
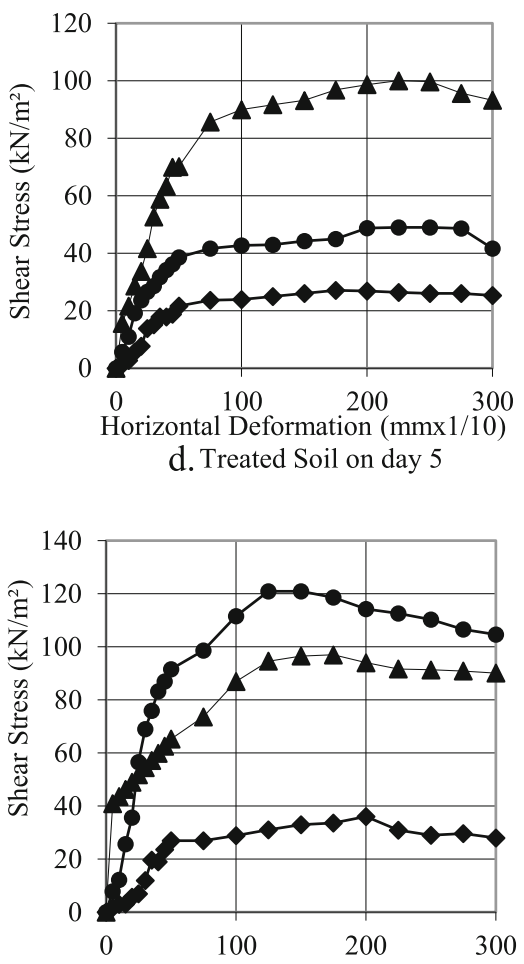

Horizontal Deformation (mmx1/10)

f. Treated Soil on day 30

Fig. 1 The shear stress-horizontal deformations of controlled and treated soil sample 


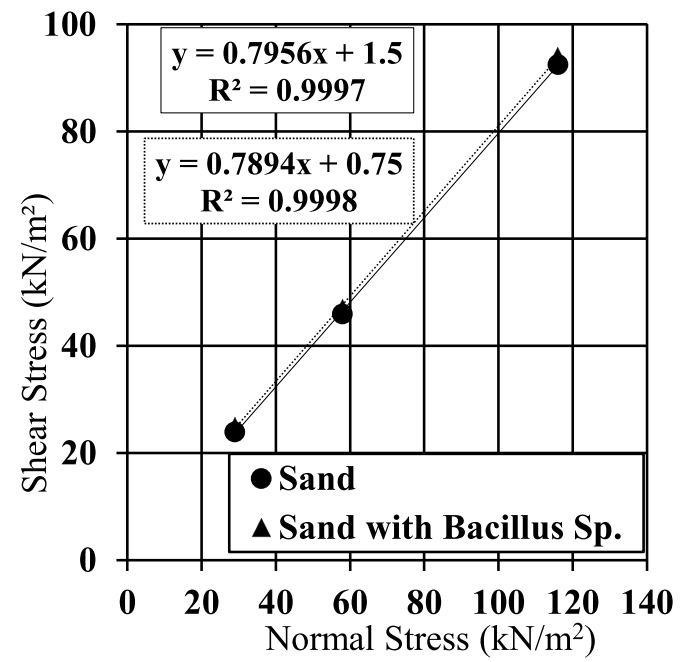

a. Treated Soil on day 1

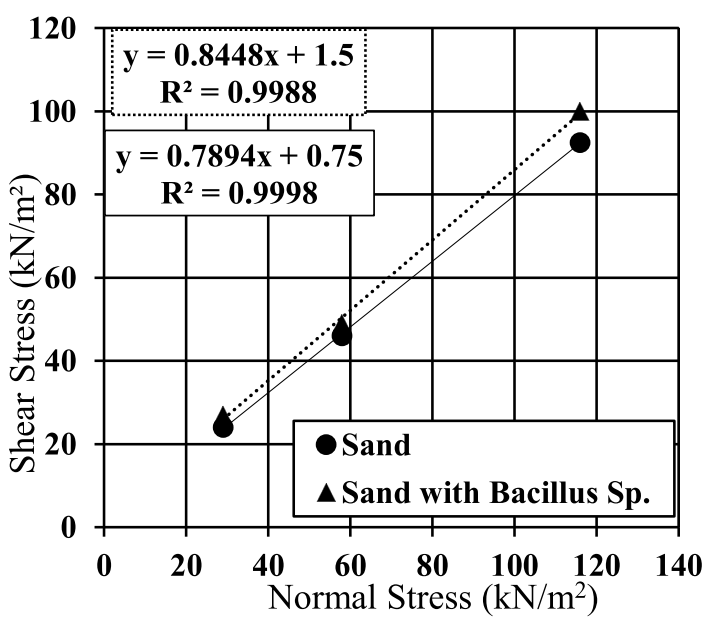

c. Treated Soil on 5 day

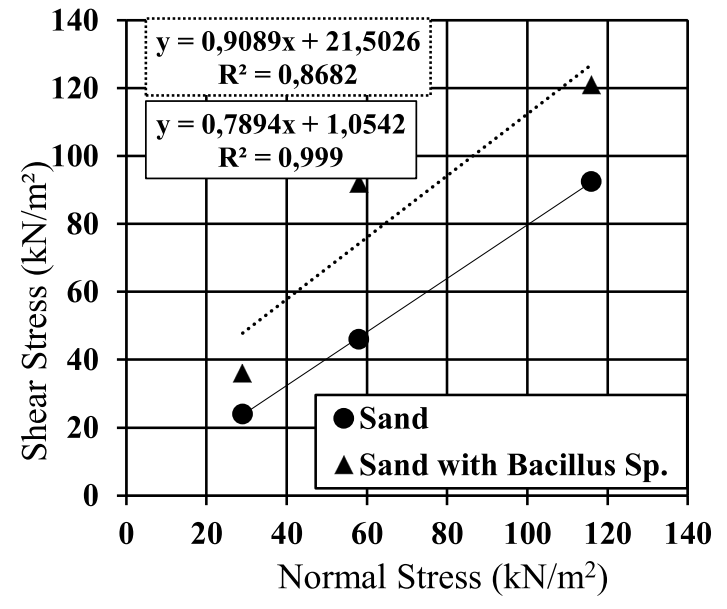

e. Treated Soil on day 30

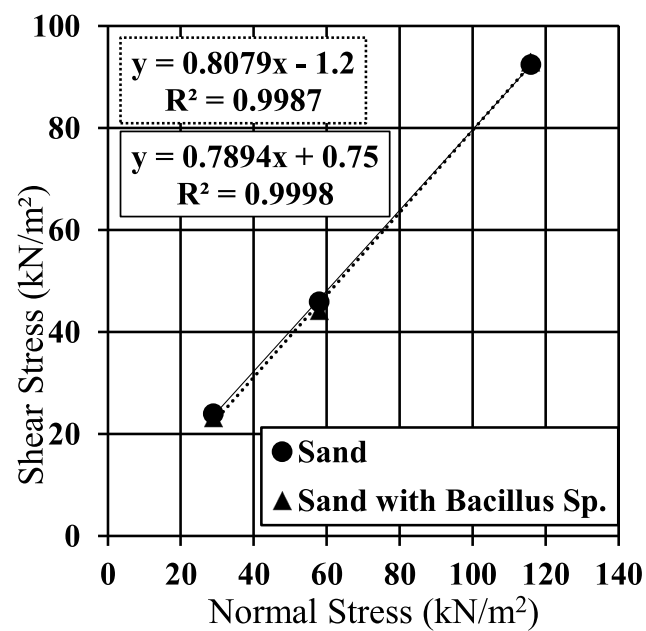

b. Treated Soil on day 2

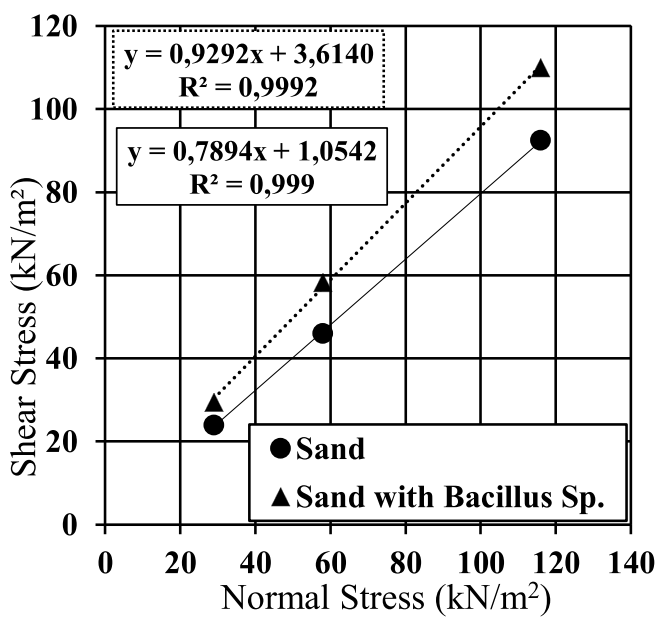

d. Treated Soil on day 15

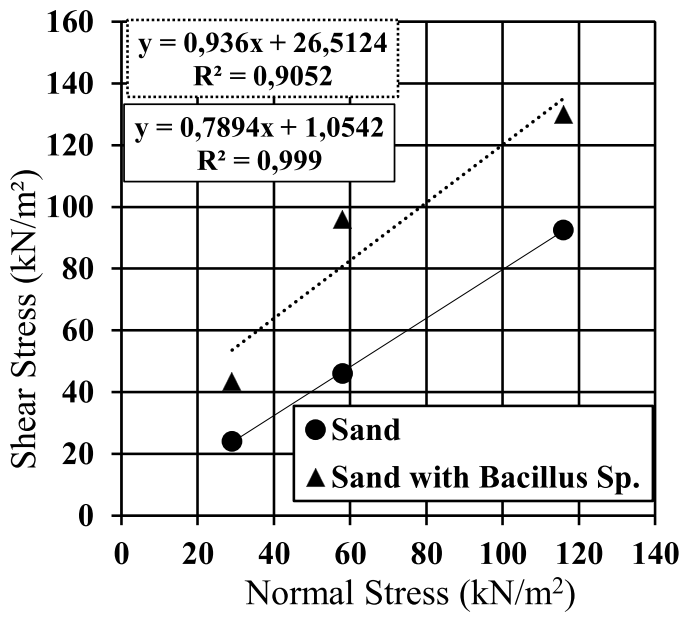

f. Treated Soil on day 45

Fig. 2 The normal stress-shear stress of controlled and treated soil samples 


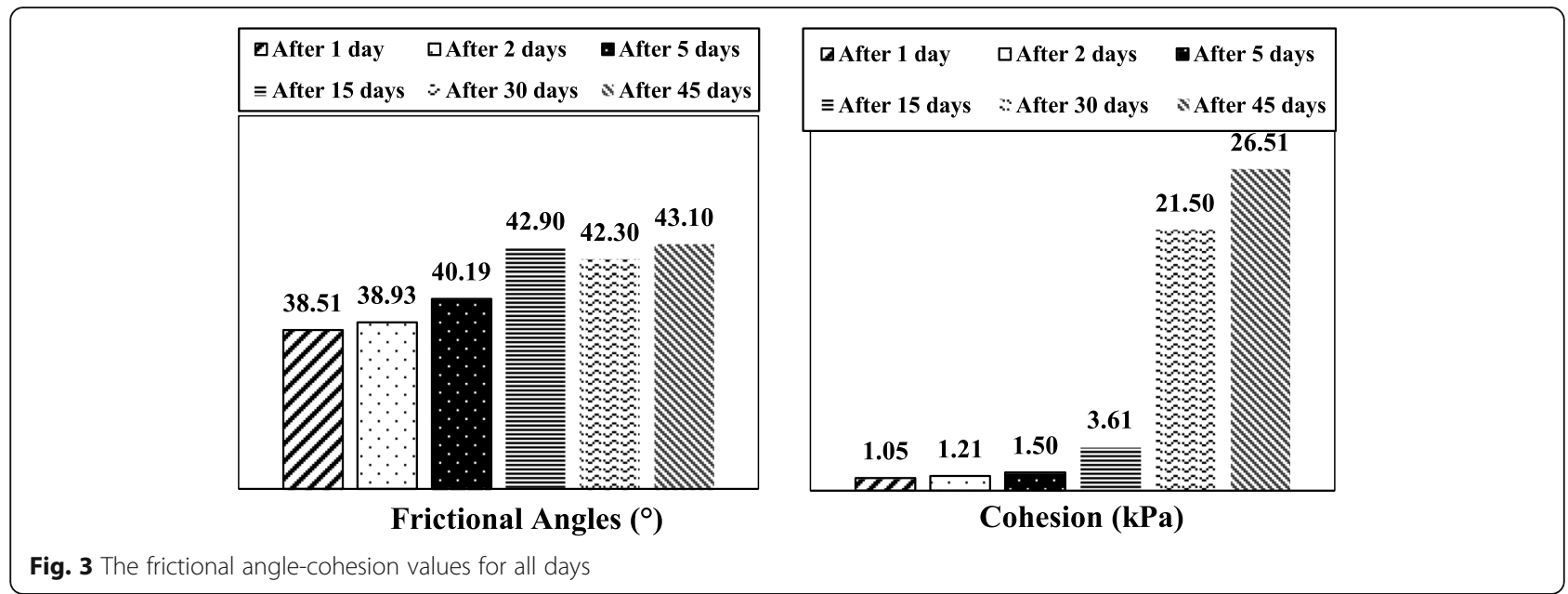

When the literature was examined, it was seen that there were studies on the subject. However, due to the limited parameters investigated, this study was conducted to investigate different parameters (time-dependent strength and hydraulic permeability change, sustainability status, etc.).

\section{Results and discussion}

\section{Soil shear strength}

The internal friction angle and cohesion were determined based on the peak shear stress using MohrCoulomb failure criterion for all soil samples (Figs. 1, 2 and 3). The internal friction angle and cohesion coefficient of the treated soil were found to be $1.05 \mathrm{kPa}$, $38.51^{\circ} ; 1.21 \mathrm{kPa}, 38.93^{\circ} ; 1.50 \mathrm{kPa}, 40.19^{\circ} ; 3.61 \mathrm{kPa}$, $42.90^{\circ}$ (Bagriacik et al., 2018); $21.50 \mathrm{kPa}, 42.30^{\circ}$; and $43.10^{\circ}$; $26.51 \mathrm{KPa}$ respectively for the 1st, 2nd, 5th 15th, 30th and 45th day of inoculation. However, the internal friction angle and cohesion coefficient of the uninoculated control soil were found to averaged $1.05 \mathrm{kPa}$ and $38.30^{\circ}$ (Bagriacik et al., 2018) respectively for the whole period of the investigation which is in agreement with other researches (Zhang et al., 2006; Dafalla, 2013; Khaleghi and Rowshanzamir, 2019). Significant increase in shear strength of the soil sample treated with the isolated bacteria can be attributed to the cementation activity induced by the bacteria $\mathrm{Ba}$ cillus sp. (Ramachandran et al., 2001; RodriguezNavarro et al., 2003; Khaleghi and Rowshanzamir, 2019). Studies relating to the effect of curing time on soil treated with Bacillus sp. and that on the changes in strength and permeability of the soil after the

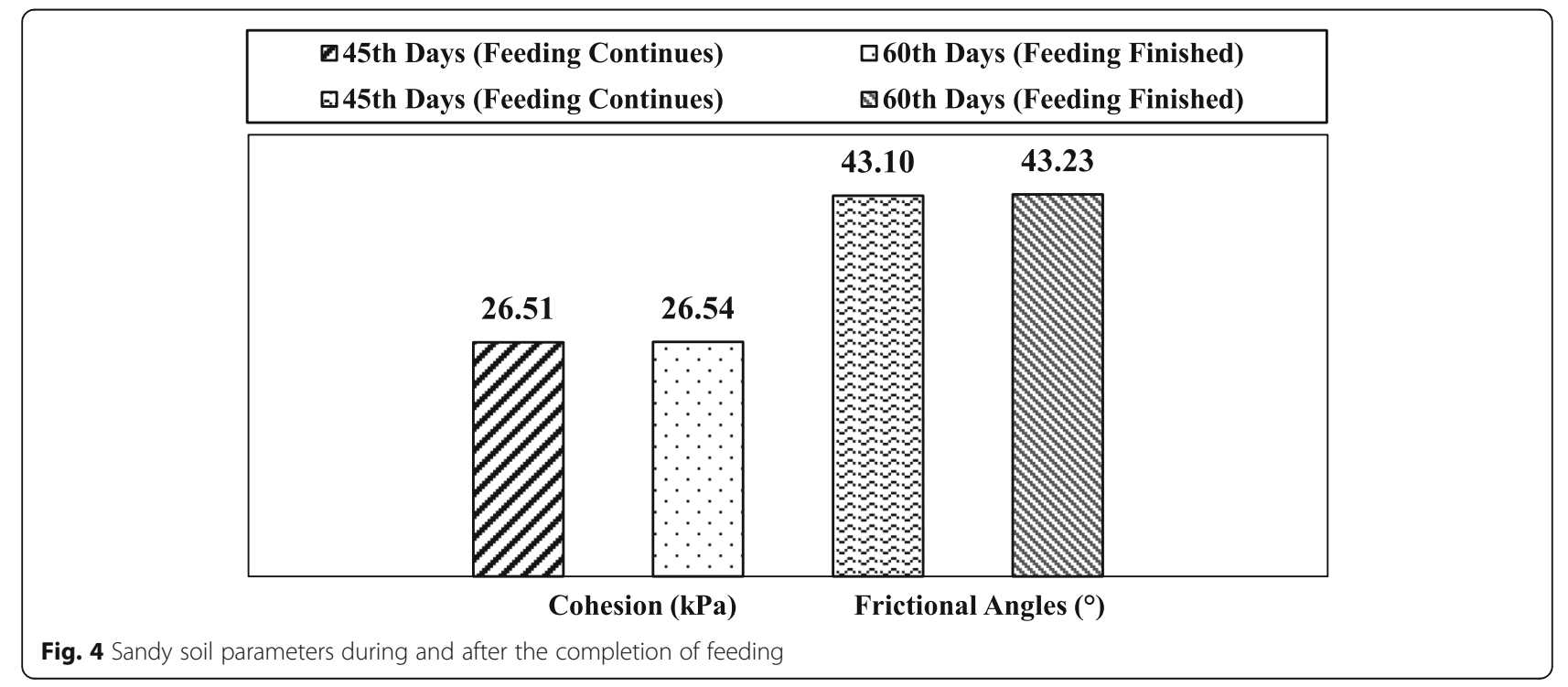




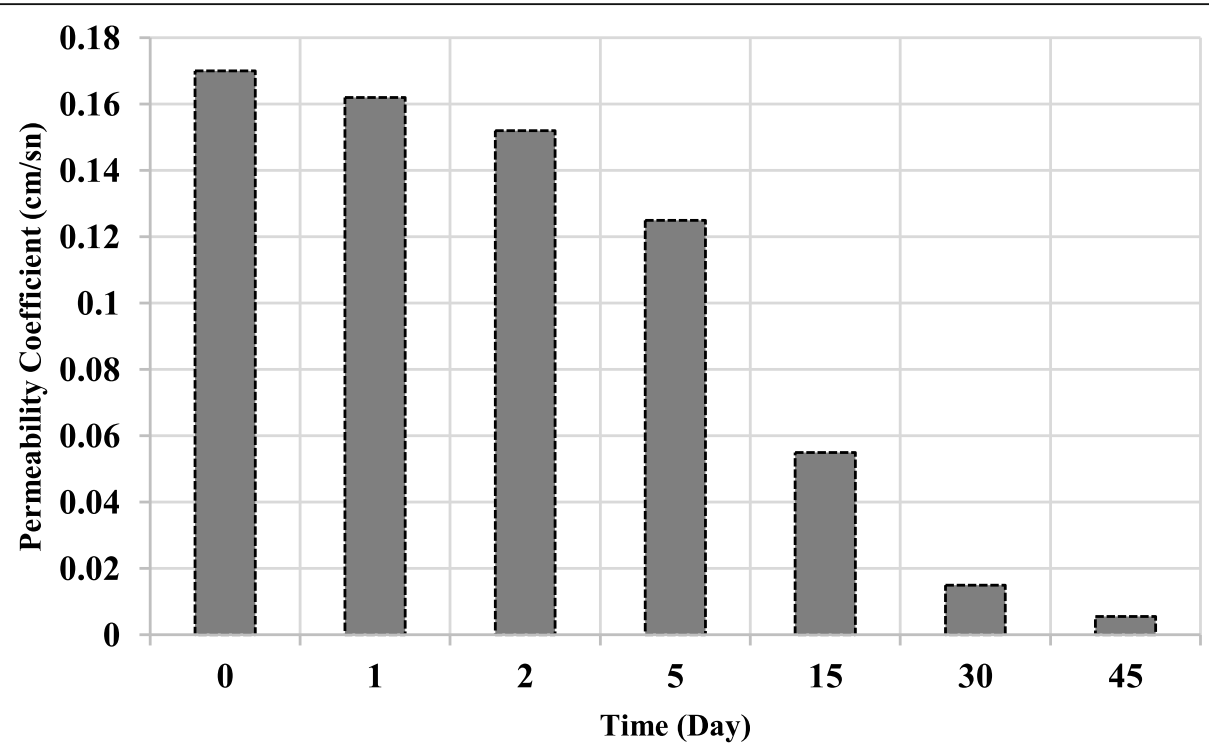

Fig. 5 Permeability coefficient of the treated soil

production of calcium carbonate by the bacteria are limited. On inoculating the soil with Bacillus sp. cementing occurs and this leads to an increase in cohesion and internal friction angles of the soil, this increase is recorded within the first 15 days, after which no significant increase in internal friction angles was recorded.

On the 15th day, 3.44 times increase in cohesion was recorded. While on day 30 and 45 an increase of 20.5 and 25.27 times were recorded. The internal friction angle of the treated was found to increase by
1.12, 1.10 and 1.12 times on day 15, 30 and 45 respectively. The results indicate that the density and consistency of the treated soil increases during the first 15 days relative to increase in internal friction angle and cohesion effected by the cementation activity induced by the inoculated bacteria.

When time-dependent analysis was conducted on the soil sample, it was observed that the increase in internal friction angle terminated on day 15 and the increase in cohesion continues on condition that the inoculated bacteria is supplied with nutrients. On not

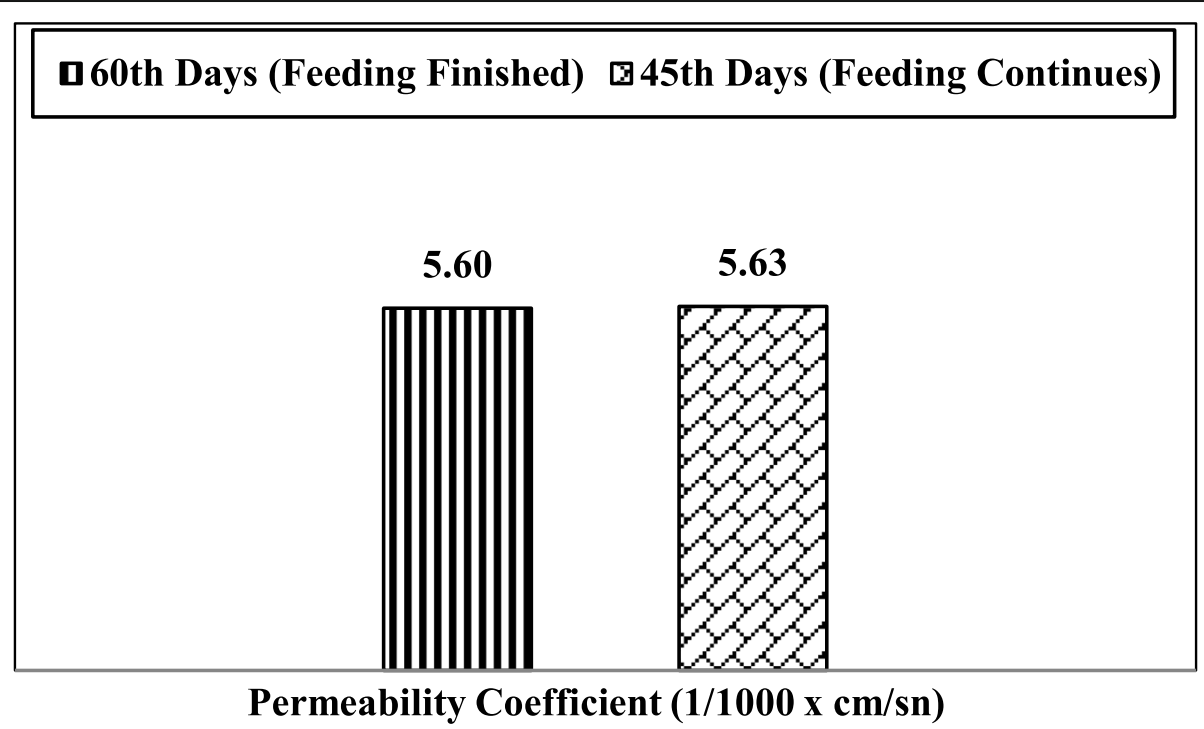

Fig. 6 Permeability coefficient during and after the completion of nutrient supply 
supplying the bacteria with nutrients increase in cohesion property of the soil stops as soon as the available nutrient in it becomes exhausted by the bacteria and this does not lead to reduction in strength of the soil (Fig. 4).

Harianto et al. (2013), Hariana et al. (2018) and Osinubi et al. (2019) reported the utilization of Bacillus leading to $80 \%$, up to 13 times and up to 6.6 times increase in soil-bearing capacity values respectively. While for this study, an increase of up to 1.12 times in internal friction angle and 25 times in cohesion value was observed after 45 days.

\section{Soil permeability}

Permeability coefficient of the soil inoculated with Bacillus sp. was observed to plummet by 30.36 times

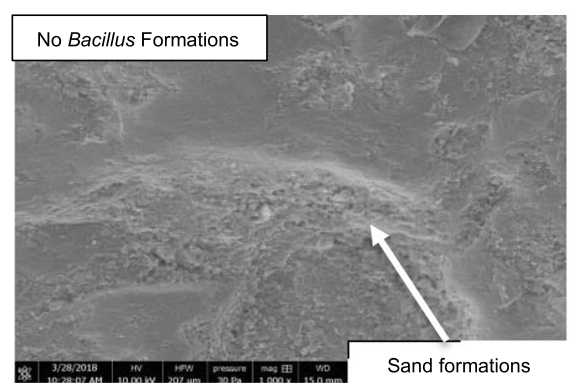

a. Sandy soil for $50 \mu \mathrm{m}$

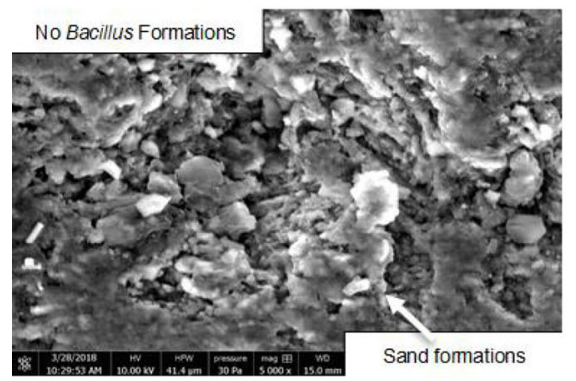

c. Sandy soil for $5 \mu \mathrm{m}$

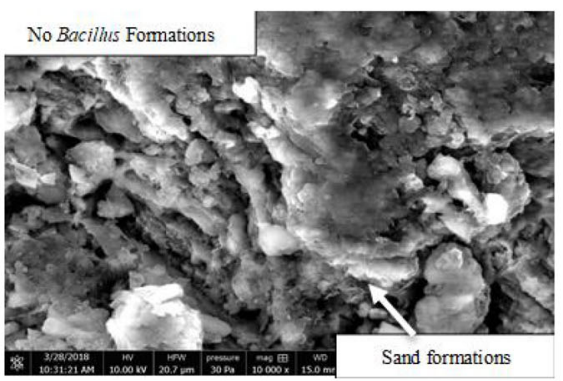

e. Sandy soil for $4 \mu \mathrm{m}$

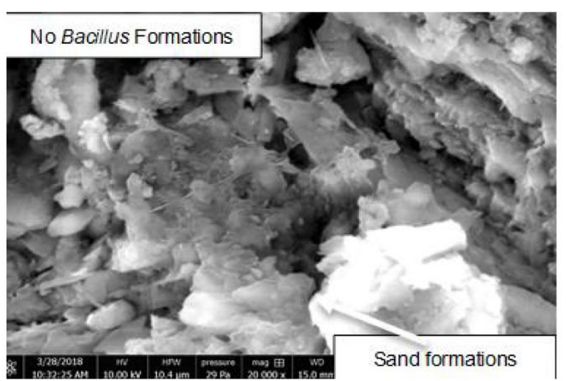

g. Sandy soil for $2 \mu \mathrm{m}$

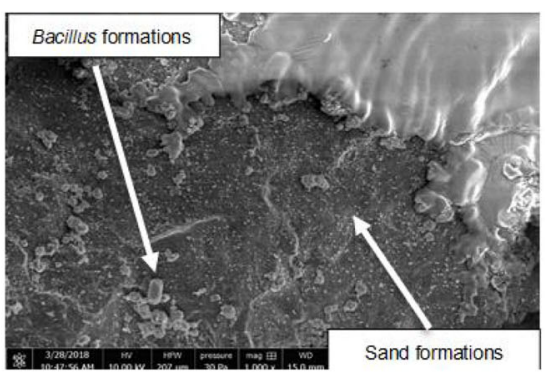

b. Sandy soil with Bacillus sp. for $50 \mu \mathrm{m}$

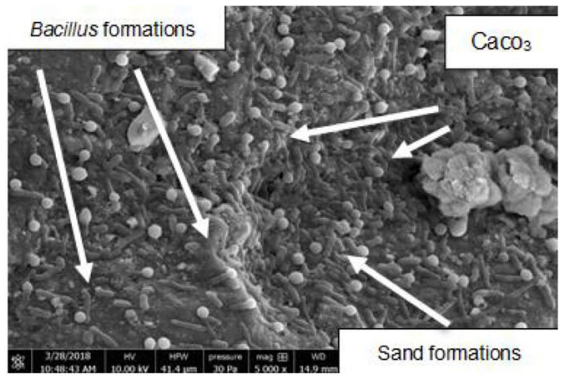

d. Sandy soil with Bacillus sp. for $5 \mu \mathrm{m}$

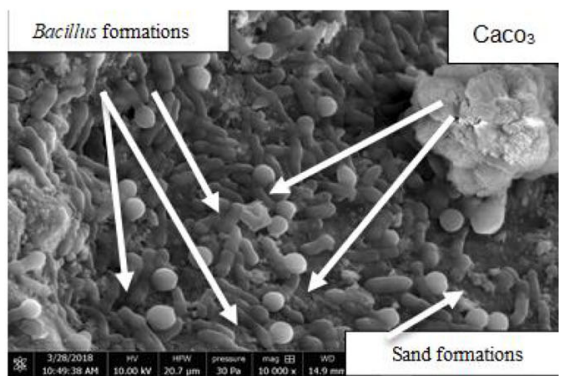

f. Sandy soil with Bacillus sp. for $4 \mu \mathrm{m}$

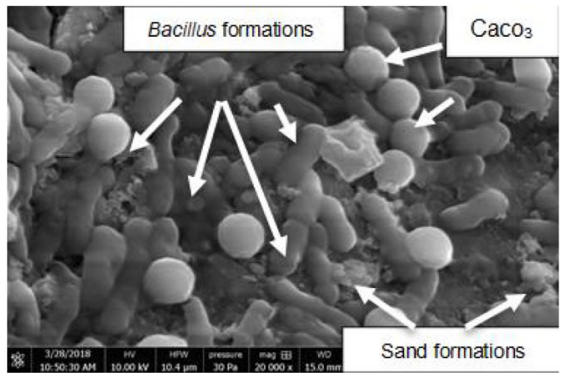

h. Sandy soil with Bacillus sp. for $2 \mu \mathrm{m}$

Fig. 7 The images of SEM before stabilization (a, $\mathbf{c}, \mathbf{e}, \mathbf{g})$ and after stabilization (b, d, $\mathbf{f}, \mathbf{h}$ ) (Bagriacik et al., 2018) 
after 45 days (Fig. 5), this can be attributed to the increase over time in the amount of calcium carbonate produced by the bacteria. Calcium carbonate produced in the soil reduces the gaps existing between soil particles thereby enhancing the resistivity of the soil against volume changes and this manifests evidently in permeability decrease of the soil. Hydraulic permeability decrease leads to the formation of more stable structure which may withstand liquefaction in the event of an earthquake. On exhaustion of the available nutrients in the treated soil, reduction in permeability was not observed (Fig. 6). Nemati and Voordouw (2003), Whiffin et al. (2007), Yasuhara et al. (2012), Harianto et al. (2013), Soon et al. (2014) and Umar et al. (2016) reported 98\%, 22-75\%, $60-70 \%, 80 \%, 90 \%$ and $90 \%$ improvements in permeability respectively while for the current research of ours we observed improvement in permeability value of up to 30.36 times after 45 days.

\section{Scanning electron microscopy (SEM) and X-ray diffraction (XRD)}

SEM investigation reveals the presence of calcium carbonate particles in soil treated with Bacillus sp.; however, the investigation shows that unlike the treated soil, in the controlled soil calcium carbonate was not present (Fig. 7). The result of X-ray diffraction analysis (XRD) of both the treated and controlled soil is presented in Tables 1 and 2 and Fig. 8, it indicates that ratio of calcium carbonate increases considerably in the soil treated with Bacillus sp. and this leads to the alteration in the chemical structure of the soil.

\section{Conclusion}

We aimed in this study to device an alternative technique of weak soil stabilization using Bacillus sp. Obtained results are presented below.

Table 1 Soil sample physical properties

\begin{tabular}{lll}
\hline Granulometric parameters & Unit & Value \\
\hline Percentage of medium-grained sand & $\%$ & 46.40 \\
Percentage of fine-grained sand & $\%$ & 53.60 \\
Effective grain size, $D_{10}$ & $\mathrm{~m}$ & 0.0018 \\
$D_{30}$ & $\mathrm{~m}$ & 0.0030 \\
$D_{60}$ & $\mathrm{~m}$ & 0.0050 \\
Coefficient of uniformity, $C_{\mathrm{u}}$ & - & 2.78 \\
Coefficient of curvature, $C_{c}$ & - & 1.00 \\
Soil class & - & $\mathrm{SP}$ \\
Maximum dry specific gravity & $\mathrm{kN} / \mathrm{m}^{3}$ & 17.06 \\
Minimum dry specific gravity & $\mathrm{kN} / \mathrm{m}^{3}$ & 15.03 \\
Specific gravity & $\mathrm{kN} / \mathrm{m}^{3}$ & 26.80 \\
\hline
\end{tabular}

Table 2 Soil sample chemical properties

\begin{tabular}{ll}
\hline Component & Sandy soil (\%) \\
$\mathrm{SiO}_{2}$ & 96.15 \\
$\mathrm{Al}_{2} \mathrm{O}_{3}$ & 2.10 \\
$\mathrm{Fe}_{2} \mathrm{O}$ & 0.6 \\
$\mathrm{MgO}$ & 0.04 \\
$\mathrm{CaO}$ & 0.22 \\
$\mathrm{MnO}$ & - \\
$\mathrm{K}_{2} \mathrm{O}$ & 0.39 \\
$\mathrm{Na}_{2} \mathrm{O}$ & 0.07 \\
$\mathrm{TiO}_{2}$ & - \\
$\mathrm{P}_{2} \mathrm{O}_{5}$ & - \\
\hline
\end{tabular}

A short time after improvement with Bacillus sp., no significant improvement was observed when the results were compared with the control samples. It showed that Bacillus sp. needed more time to produce calcium carbonate, and it was understood that such improvements would not yield fruitful results in a short time. However, there have been significant improvements in the engineering properties of the soil over time. This situation is thought to be due to the increase in the attraction force between the sand grains due to the calcium carbonate produced. It was observed that the intergranular attraction forces due to the produced calcium carbonate increased and the gaps decreased. Thus, the resistance of the soil to volume changes increased and the hydraulic permeability decreased. In addition, a more stable structure was created against settlements and the risk was reduced in the sand that has the potential to liquefy during an earthquake. There was no decrease in the improvements in the engineering properties of the soil after the nutrient that should be given to the bacteria to produce calcium carbonate was cut off. This showed that the improvement with Bacillus sp. was sustainable. Alternative methods are needed due to the fact that the traditional additives (such as cement, fly ash) used in the improvement of sandy soils emit $\mathrm{CO}_{2}$ to nature during the production and use and their costs are high. With this study, it was determined that sandy soils can be improved with Bacillus sp., an environmentally friendly and economical approach, and this improvement is sustainable.

\section{Methods}

Physical and chemical characterization of the soil

Sandy soil samples were collected from the riverbed of Seyhan river $\left(37^{\circ} 05^{\prime} 37.3^{\prime \prime} \mathrm{N} 35,35^{\circ} 12^{\prime} 31.7^{\prime \prime}\right.$ E) Adana, Turkey, and were oven-dried. Physico-chemical 


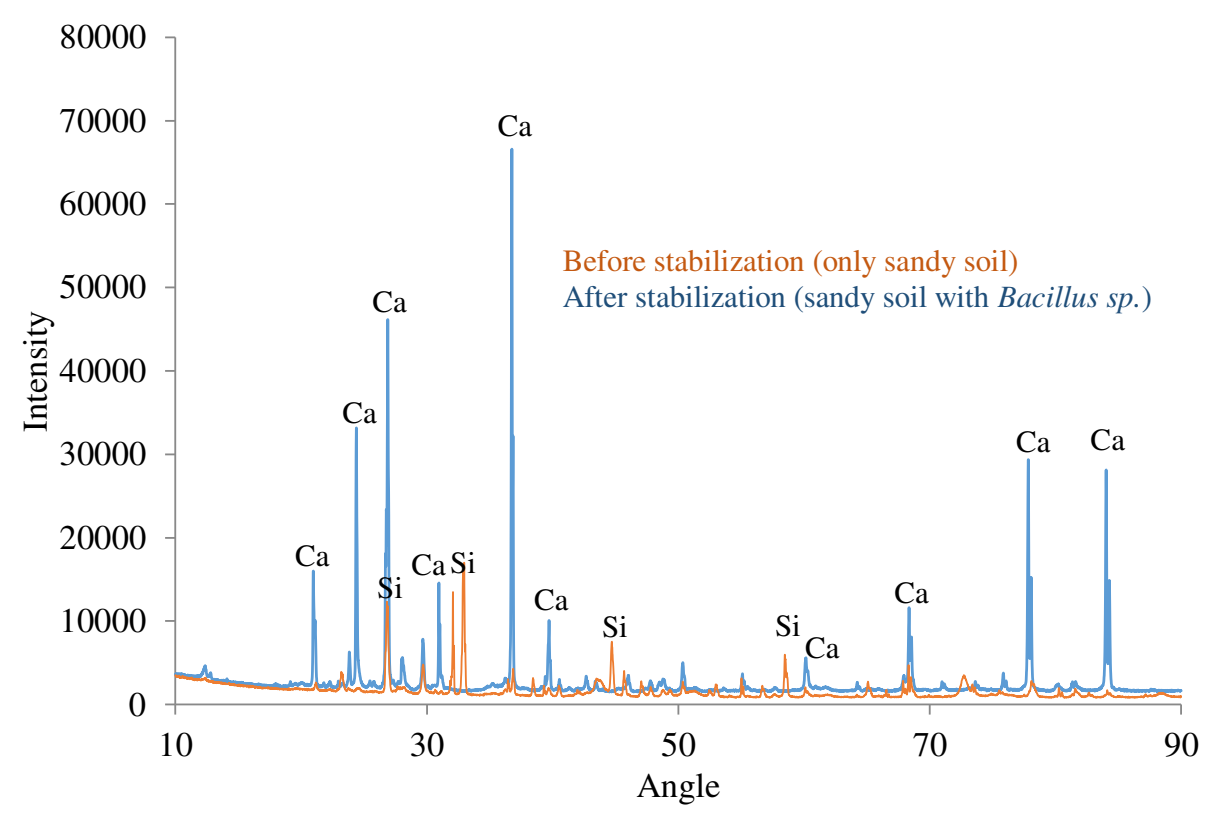

Fig. 8 XRD analysis result of inoculated and uninoculated soil

characterization of the collected samples was conducted according to ASTM D 6913-04 established protocols.

The particle size distribution of the sample was found to be $53.6 \%$ fine grain and $46.4 \%$ medium grain sand (Fig. 9). The soil was found to have $26.80 \mathrm{kN} / \mathrm{m}^{3}$ specific gravity, $15.03 \mathrm{kN} / \mathrm{m}^{3}$ minimum dry specific gravity and $17.06 \mathrm{kN} / \mathrm{m}^{3}$ maximum dry specific gravity. Tables 1 and 2 presents the physical and chemical properties of the soil sample under study.

\section{Isolation and characterization of microorganisms}

Urea hydrolysing bacteria was isolated from the rhizosphere soil of Thuja orientalis and Pinus pinea trees. Soil samples were collected from the rhizosphere of the

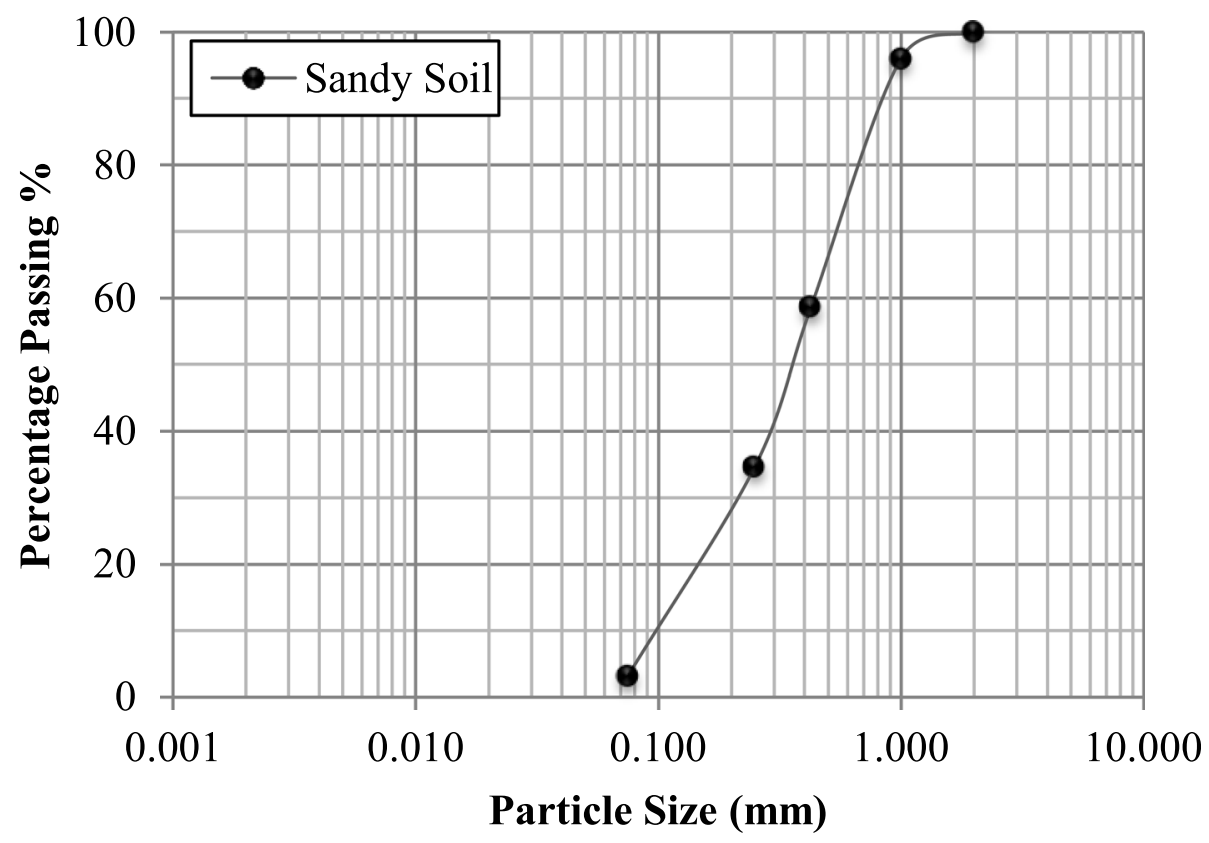

Fig. 9 Sieve analysis of soil sample 
aforesaid plants and $2 \mathrm{~g}$ from each of the samples was homogenized in $10 \mathrm{ml}$ serum physiologic buffer, the resultant suspension was incubated at $85{ }^{\circ} \mathrm{C}$ for $15 \mathrm{~min}$ with the aim of eliminating non-spore forming bacteria. One hundred microliters of the heat-treated sample suspension was spread plated on urea agar and incubated at $37^{\circ} \mathrm{C}$ for $24 \mathrm{~h}$.

To determine the urea hydrolysing ability of the isolates, the isolates were inoculated on a urea agar ( $\mathrm{gL}^{-1}, 20 \mathrm{~g}$ urea, $9.5 \mathrm{~g} \mathrm{Na}_{2} \mathrm{HPO}_{4}, 9.1 \mathrm{~g} \mathrm{KH}_{2} \mathrm{PO}_{4}, 0.1 \mathrm{~g}$ yeast extract, $0.01 \mathrm{~g}$ phenol red, $12 \mathrm{~g}$ agar $\mathrm{pH}, 6.8$ ) slant and incubated at $37{ }^{\circ} \mathrm{C}$ for $2-5$ days. Development of pink colour was considered a positive result. Positive strains were stored in glycerol stock for use in subsequent experiments.

The identity of the isolated bacteria was determined through the amplification and sequencing of its 16s rRNA gene using $27 f / 519 r$ primers. The 16sRNA gene sequence of the bacteria was aligned with known sequences using the BLAST algorithm in the NCBI database. The bacterium was identified as Bacillus sp. (accession number NR_114919.1) (Fig. 10).

\section{Media preparation}

The urea medium for the experimental study was prepared by dissolving $3 \mathrm{~g}$ nutrient broth powder, $20 \mathrm{~g}$ urea, $10 \mathrm{~g} \mathrm{NH}_{4} \mathrm{Cl} 10 \mathrm{gL}^{-1}, 2.12 \mathrm{~g} \mathrm{NaHCO}_{3}$ in $1 \mathrm{l}$ of distilled water. The $\mathrm{pH}$ of the solution was adjusted to 6.0 and autoclaved at $120{ }^{\circ} \mathrm{C}$ for $15 \mathrm{~min}$ and $20 \mathrm{ml}$ of calcium chloride solution $\left(\mathrm{CaCl}_{2} \cdot 2 \mathrm{H}_{2} \mathrm{O} 18.5 \mathrm{~g} / 100 \mathrm{~mL}\right)$ was added to the autoclaved medium to support $\mathrm{CaCO} 3$ formation (Canakci et al. 2015).

\section{Treatment of sandy soils}

Urease-positive strain selected for use in the experiments was inoculated into the urea medium. The bacteria produced were precipitated by centrifugation at $9.000 \mathrm{rpm}$ for $5 \mathrm{~min}$ while in the logarithmic phase and the pelleted part was taken and resuspended in a fresh urea medium. The final bacterial density was determined as $1.2 \times 10^{6} \mathrm{cfu} / \mathrm{ml}$ by counting with the Petroff-Hausser slide. Twenty millilitres of the prepared bacterial culture was injected into the soil samples. Soil samples used as the control group were treated with bacteria-free urea medium. Twenty millilitres of medium was added to all samples every $6 \mathrm{~h}$ for 15 days by passing it through a sterile filter of $0.22-\mu \mathrm{m}$ diameter.

\section{Direct shear test}

Direct shear test was conducted on the collected soil sample using the apparatus depicted in Fig. 11 to determine the shear properties, cohesion and internal friction angle $(\phi)$ of the soil. The apparatus consists of a soil shear box, a loading head, a weight hanger and weights to generate normal loads. The shear box has two square rings for holding soil sample. The box has a crosssection of $60 \times 60$ and a height of $50.8 \mathrm{~mm}$. Horizontal displacement of the movable ring is achieved with a motor. A load cell measures the shear force. Two potentiometers measure the horizontal and vertical displacements. Values of shear force and horizontal displacement is recorded by a computer data acquisition system (Sadek et al., 2011). The test was conducted using ASTM D 3080 standards.

Bacillus sp. was inoculated into the soil sample. The inoculated soil was dried in an oven fed on the

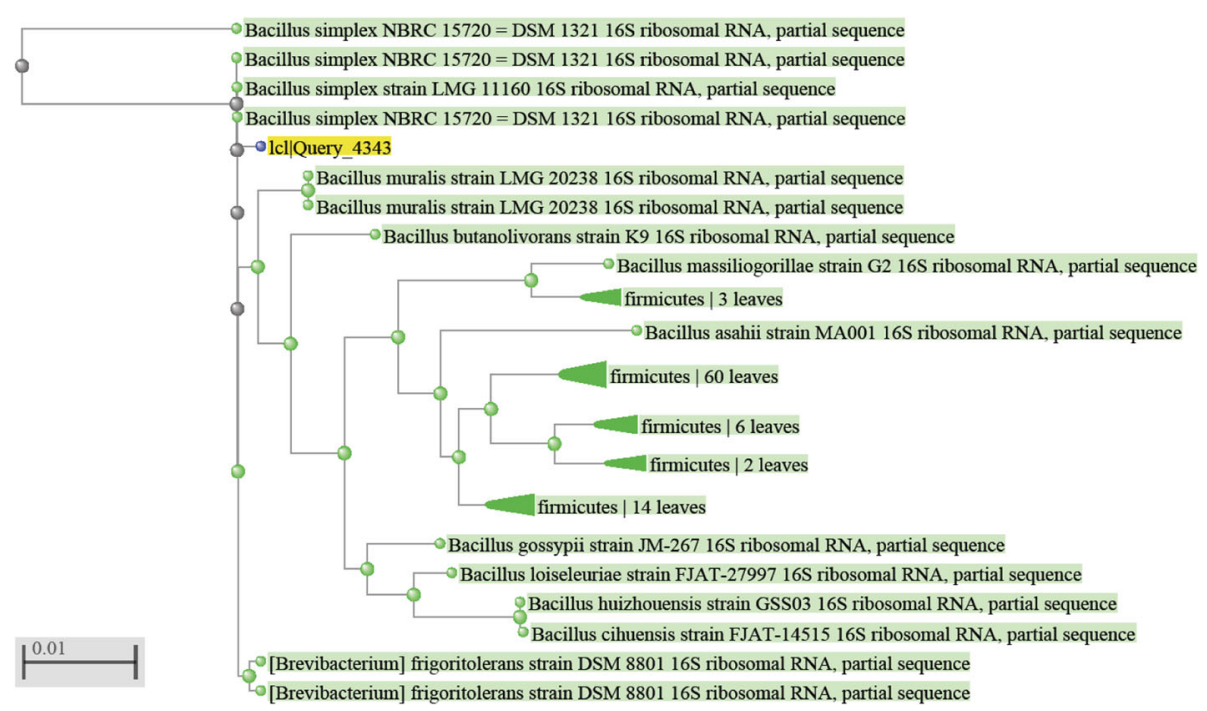

Fig. 10 The phylogenetic tree of the microorganism (NCBI website) 


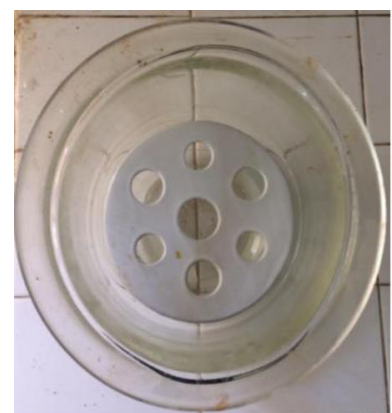

a. Preparation container

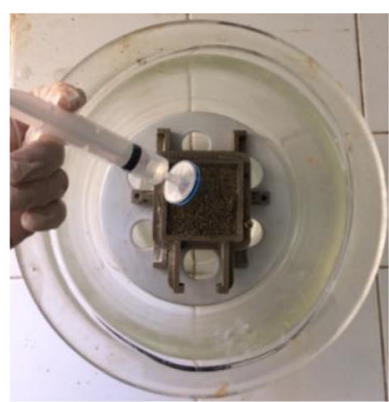

d. Injection of Urea medium

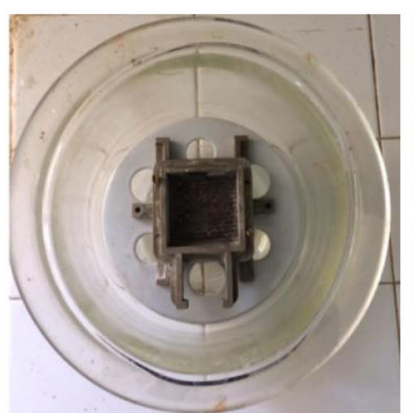

b. Test cup assembly

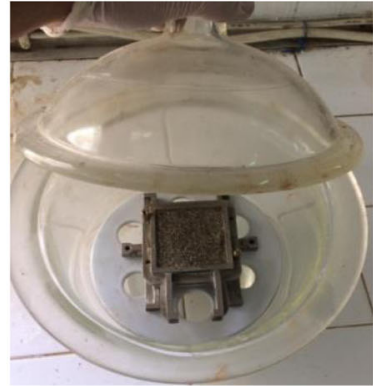

e. Sample protection

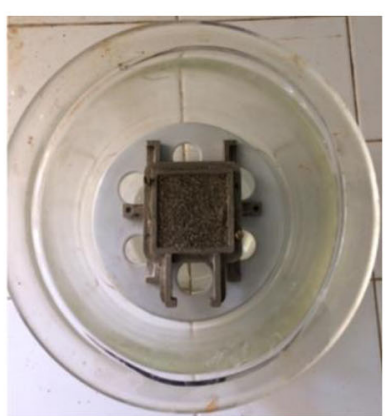

c. Soil sample introduction

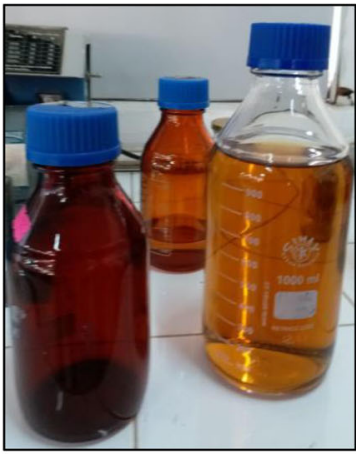

f. Bacillus sp. growth medium

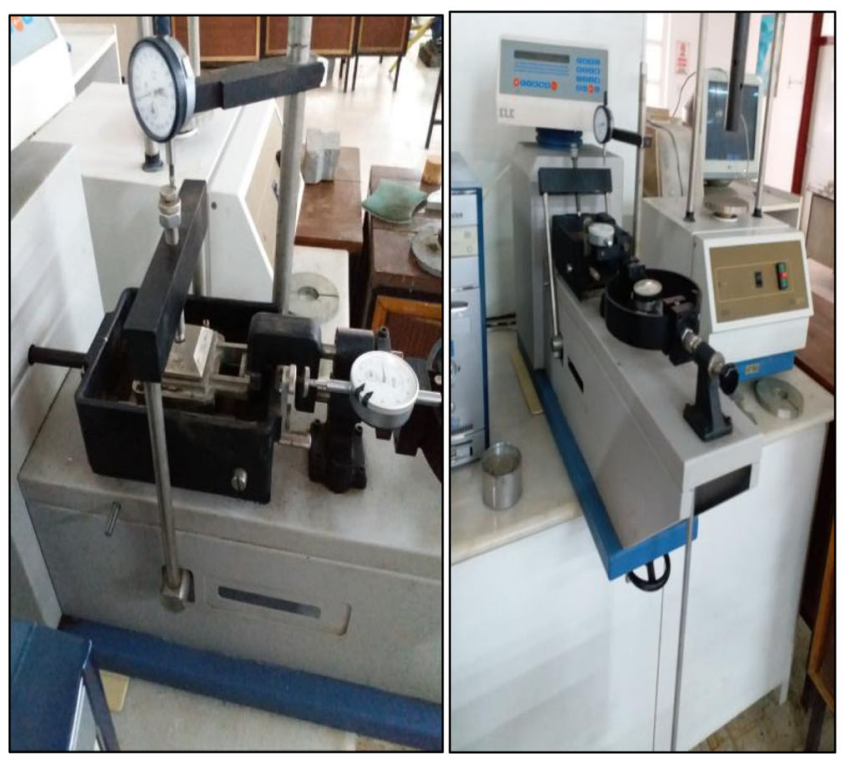

g. Vertical load application on sample

h. Direct shear test machine

Fig. 11 Direct shear test setup

1st, 2nd, 5th, 15th, 30th and 45th day of inoculation, cohesion (c) and internal friction angle $(\phi)$ of the soil were determined. Uninoculated soil sample served as a negative control.

\section{Permeability test}

The permeability of the soil sample under analysis was determined in accordance with ASTM D2434-19 standard (Fig. 12). Readings were taken throughout the 


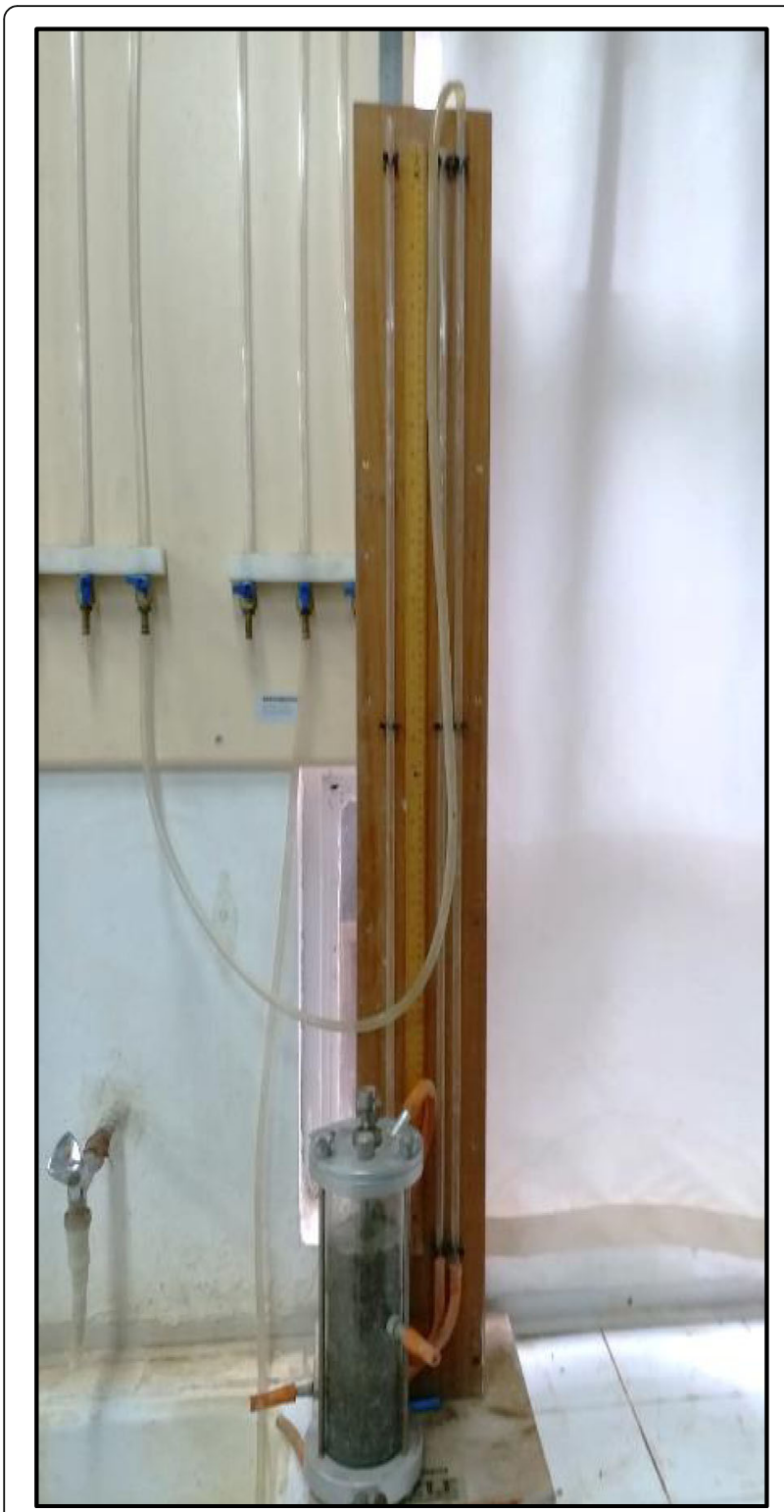

Fig. 12 Permeability test setup

permeability test at different time intervals and permeability coefficients determined.

\section{The microstructural analysis}

In the study, SEM analyses were performed to observe the formation of Bacillus sp. on sandy soils. The SEM of each sample was performed by the FEI-QUANTAFEG650. The XRD of each sample was obtained using a Rigaku Miniflex XRD equipped with radiation. The material phases were identified through PDXL software using the current database.

\section{Acknowledgements}

Not applicable.

\section{Authors' contributions}

BB: Conducting experiments, article writing, literature search and writing evaluation of results and review of article language.

ZKS: Literature search and writing and article language review.

FMU: Isolation and characterization of Bacillus sp.

ESY: Isolation and characterization of Bacillus sp.

SD: Article writing, evaluation of results and article language review.

The authors read and approved the final manuscript.

\section{Funding}

The authors declare that funding was not received for this publication.

\section{Availability of data and materials}

The authors declare that all materials and data are available upon request.

\section{Declarations}

Ethics approval and consent to participate

Not applicable.

\section{Consent for publication}

Not applicable.

\section{Competing interests}

The authors declare that they have no competing interests.

\section{Author details}

${ }^{1}$ Department of Civil Engineering, Faculty of Engineering, Cukurova

University, Balcali, 01330 Adana, Turkey. ${ }^{2}$ Department of Biology, Faculty of

Science and Letter Cukurova University, Balcali, 01330 Adana, Turkey.

Received: 18 March 2021 Accepted: 27 July 2021

Published online: 09 September 2021

\section{References}

ASTM D 6913-04. Standard test methods for particle-size distribution (gradation) of soils using sieve analysis.

ASTM D2434-19. Standard Test Method for Permeability of Granular Soils.

ASTM D3080. Standard Test Method for Direct Shear Test of Soils Under Consolidated Drained Conditions.

Bachmeier KL, Williams AE, Warmington JR, Bang SS (2002) Urease Activity in Microbiologically-Induced Calcite Precipitation. J. Biotech 93(2):171-181

Bagriacik, B., Yigittekin E.S., Uslu F.M., Dincer S. (2018). Improvement of Engineering Properties of Sandy Soils by Bacillus simplex, 4th International Conference on Environmental Science and Technology, 87-93.

Bang SS, Galinat JK, Ramakrishnan V (2001) Calcite precipitation induced by polyurethane immobilized Sporosarcina pasteurii. Enzym. Microb. Technol 28: 404-409

Canakci, H., Sidik, W., Kilic I.H. (2015). Effect of bacterial calcium carbonate precipitation on compressibility and shear strength of organic soil, Soils and Foundations, Part A 55 (5), 1211-1221.

Chu J., Stabnikov V., Ivanov V. (2012). Microbially induced calcium carbonate precipitation on surface or in the bulk of soil, Geomicrobiology Journal 2012; 29(6):544e9.

Dafalla, M.A. (2013). Effects of clay and moisture content on direct shear tests for claysand mixtures. Adv. Mater. Sci. Eng.

Dejong, J.T., Fritzges, M.B., Nusslein, K. (2006). Microbially induced cementation to control sand response to undrained shear, J. Geotech. Geoenviron. Eng. 132, 1381-1392ASCE 1090-0241.

Dejong JT, Mortensen BM, Martinez BC, Nelson DC (2010) Biomediated soil improvement. Ecol. Eng 36(2):197-210

Douglas S, Beveridge TJ (1998) Mineral formation by bacteria in natural Communities. FEMS Microb Ecol. 26:79-88

Ferris FG, Stehmeier LG, Kantzas A, Mourits FM (1997) Bacteriogenic mineral plugging. Journal of Canadian Petroleum Technology 36(9)

Filet AE, Gadret JP, Loygue M, Borel S. (2012). Biocalcis and its applications for the consolidation of sands. In: Grouting and deep mixing, American Society of Civil Engineers (ASCE); 2012. p. 1767-1780.

Gollapudi UK, Knutson CL, Bang SS, Islam MR (1995) A new method for controlling leaching through permeable channels. Chemosphere 30:695-705 
Harianto, T., Hamzah, S., Nur, S.H., Abdurrahman, M.A., Latief, R.U., Fadliah, I., Walenna, A. (2013). Biogrouting Stabilization On Marine Sandy Clay Soil, Proceedings of the 7th International Conference on Asian and Pacific Coasts, Indonesia, September 24-26, 2013 848-852

Hasriana, L., Samang, L., Harianto, T., Djides, M.N. (2018) Bearing capacity improvement of soft soil subgrade layer with Bio Stabilized Bacillus Subtilis. MATEC Web of Conferences. 181. 01001. https://doi.org/10.1051/matecconf/2 01818101001

Ivanov V, Chu J (2008) Applications of microorganisms to geotechnical engineering for bioclogging and biocementation of soil in situ. Reviews in Environmental Science and Biotechnology 7(2):139-153

Jonkers HM, Thijssen A, Muyzer G, Copuroglu O, Schlangen E (2009) Application of bacteria as self-healing agent for the development of sustainable concrete. Ecol. Eng 12(36):3-6

Khaleghi M, Rowshanzamir MA (2019) Biologic improvement of a sandy soil using single and mixed cultures: A comparison study. Soil \& Tillage Research 186:112-119

Lo Bianco, A., Madonia, G. (2007). B.U.L.M. technique for increase of the bearing capacity in the pavement layers subjected to biological treatment, University of Palermo, 4th International Siiv Congress, Palermo (Italy).

Nemati M, Voordouw G (2003) Modification of porous media permeability, using calcium carbonate produced enzymatically in situ. Enzyme and Microbial Technology 33(5):635-642

Osinubi, K.J., Yohanna, P., Eberemu, A.U., ljimdiya, T.S. (2019). Unconfined Compressive Strength of Lateritic Soil Treated with Bacillus Coagulans for use as Liner and Cover Material in Waste Containment System. IOP Conference Series: Materials Science and Engineering. 640. 012081. https://doi.org/10.1 088/1757-899X/640/1/012081

Ramachandran, S.K., Ramakrishnan, V., Bang, S.S. (2001). Remediation of concrete using micro organisms, ACl Mater. J., 98, 3-9

Ramakrishnan V (2007) Performance characteristics of bacterial concrete-a smart biomaterial. In: Proceedings of the First International Conference on Recent Advances in Concrete Technology. Washington, DC, pp 67-78

Rodriguez-Navarro C, Rodriguez-Gallego M, Chekroun KB, Gonzalez-Muñoz MT (2003) Conservation of ornamental stone by Myxococcus xanthus-induced carbonate biomineralization. Appl. Environ. Microbiol 69(4):2182-2193

Sadek MA, Chen Y, Liu J (2011) Simulating shear behavior of a sandy soil under different soil conditions. Journal of Terramechanics 48:451-458

Sarda, D., Choonia, S., Sarode, D.D., Lele, S.S. (2009). Biocalcification by Bacillus pasteurii urease: A novel application, J. Ind. Microbiol. Biotechnol, 36 (8), 1111-1115.

Soon NW, Lee LM, Khun TC, Ling HS (2013) Improvements in engineering properties of soils through microbial-induced calcite precipitation. KSCE Journal of Civil Engineering 17(4):718-728

Soon NW, Lee LM, Khun TC, Ling HS (2014) Factors affecting improvement in engineering properties of residual soil through microbial-induced calcite precipitation. Journal of Geotechnical and Geoenvironmental Engineering 40(5)

Stocks FS, Galinat JK, Bang SS (1999) Microbiological precipitation of $\mathrm{CaCO}_{3}$, Soil Biol. Biochem. 31(11):1563-1571

Umar M, Kassim KA, Chiet KTP (2016) Biological process of soil improvement in civil engineering: A review. Journal of Rock Mechanics and Geotechnical Engineering 8(5):767-774

Whiffin VS, van Paassen LA, Harkes MP (2007) Microbial carbonate precipitation as a soil improvement technique. Geomicrobiol. J 25(5):417-423

Yasuhara H, Neupane D, Hayashi K, Okamura M (2012) Experiments and predictions of physical properties of sand cemented by enzymaticallyinduced carbonate precipitation. Soils and Foundations 52(3):539-549

Zhang MX, Javadi AA, Min X (2006) Triaxial tests of sand reinforced with 3D inclusions. Geotext. Geomembr. 24(4):201-209

\section{Publisher's Note}

Springer Nature remains neutral with regard to jurisdictional claims in published maps and institutional affiliations.

Ready to submit your research? Choose BMC and benefit from:

- fast, convenient online submission

- thorough peer review by experienced researchers in your field

- rapid publication on acceptance

- support for research data, including large and complex data types

- gold Open Access which fosters wider collaboration and increased citations

- maximum visibility for your research: over $100 \mathrm{M}$ website views per year

At BMC, research is always in progress.

Learn more biomedcentral.com/submissions 